\title{
Domestic Tourism Development and Anchor Attractions: 'Tourisming' the Small Towns in Zimbabwe - The Tourists' Perspectives.
}

\author{
Farayi Phillip Kanokanga ${ }^{1}$, Patrick Walter Mamimine ${ }^{2}$, Charity Mapingure ${ }^{3}$, \\ Kumbirai Mirimi ${ }^{4}$, Margaret Nyarota ${ }^{5}$ \\ 1, 2, 3, 4,5 Hospitality and Tourism Department, School of Hospitality and Tourism, Chinhoyi University \\ of Technology, Zimbabwe
}

\begin{abstract}
The problem is that more often than not tourism is perceived as an event rather that a process. Another error of perception is that the destination is seen as a pin - point area rather that an environment that can hardly be precisely defined. The Zimbabwe Tourism Authority (ZTA's) tourism and hospitality statistics derive from the country's renowned destinations. Small towns are omitted. Tourism and hospitality statistics of some fairly big towns are added to those of anchor attractions. Unless the problem is resolved, the tourism potential of small towns will not be fully tapped. The paper investigated opportunities for domestic tourism development in the small towns of Chinhoyi and Karoi. It is crucial to view tourism as a much broader phenomenon occurring in a broader context. It does not seem prudent to allocate resources to much publicised destinations ignoring what one could term the tourism corridor. A survey of 55 randomly selected domestic tourists in the two towns revealed that holiday experiences of the majority (51\%) of respondents would improve through the provision of historical tourism. Forty three per cent required events and a variety of entertainment. Thirty per cent needed nature - based tourism. Family - oriented facilities were also proposed. The study recommended that route tourism be a subject of scholarly inquiry in Zimbabwean tourism.
\end{abstract}

Keywords: anchor attractions, domestic tourism development, small towns, tourism corridor, 'tourisming'

\section{Introduction}

There is quite often the view that international tourism is 'the tourism' and domestic tourism - 'the other tourism'. Domestic tourism is often relegated to the periphery of the tourism system. It tends to assume second class status and yet it is indeed big business. According to the World Tourism Organisation, (UNWTO), domestic tourism is estimated to be ten times greater in volume than international tourism and yet comparatively little research has been undertaken on this neglected area of tourism activity. Pearce (1995) cited in [1] notes that although the scale and volume of domestic tourism worldwide exceed that of international tourism, it continues to be treated as the poorer partner in the compilation of statistics. The UNWTO reports that there were 4 billion domestic arrivals worldwide in 2008 against 917 million international arrivals.

Reference [2] reports that their study estimates that domestic tourism contributions, in comparison with international visitor contributions, were as high as 60 per cent of the total tourism income. It steers clear from providing more detailed numbers due to disparities in methodology and accounting systems and calculations which make it very difficult to give exact figures that are reliable and comparable. The Southern African Development Community (SADC) region and Zimbabwe in particular are interested in new product development focusing on domestic tourism. 'Tourisming' refers to developing tourism in the small towns.

\subsection{Market Trends}

According to reference [3], new market trends indicate that tourists are increasingly seeking a varied holiday, which combines a number of attractions and leisure opportunities within the same trip. The interest is no longer in visiting a single famous resort or a number of resorts, but also in exploring the 'context' where they are located. Consequently, the satisfaction experienced by the visitor does not merely depend on the quality of each visit made, but also on their perception of the whole tourist region. The understanding of such behaviour and its implications for the area is the basic element of meeting the visitor's expectations and guarantee the quality of life for residents. While it is critical to establish current and future travel trends of domestic tourists in a particular geographical area, those trends should be considered in light of global trends unravelled by scholars like [3]. In light of research findings by tourism scholars, it is most likely that domestic tourists travelling on the Harare - Kariba route will behave as discovered above. This adds weight to the idea of developing small towns for domestic tourism. Small towns, which are often transit towns, contribute to the tourist's perception of the entire tourist region or tourism corridor. Leiper (1990) alludes to this using his tourism model. 


\subsection{Leiper's Tourism System}

Reference [1] observe that Leiper (1990) identifies a tourism system as comprising a tourist, a traveller - generating region, tourism destination regions; transit routes for tourists travelling between generating and destination areas, and the travel and tourism industry (for example, accommodation, transport, the firms and organisations supplying services and products to tourists). Leiper (1990) says in his framework transport forms an integral part of the tourism system, connecting the tourist - generating and destination region together. However, it appears that Leiper (1990) could not envisage a scenario whereby the points along the transit route or the tourism corridor could be developed to become destinations themselves. The other view is that what one calls transit route could be a destination for another. There is an assumption that a transit route will remain so for perpetuity. It is viewed more as a region to traverse with focus put on transport and transportation and not really as a vital tourism resource that could be utilised to generate memorable experiences for the visitor. According to Leiper (1990), a 'system' can be defined as a set of elements or parts that are connected to each other by at least one distinguishing principle. In this case, tourism is the distinguishing principle which connects the different components in the system around a common theme.

Reference [4] state that Williams, in Arizona (population 2,529) is a typical small town that over the previous hundred years has experienced the rise and fall of resource extraction industries such as logging, ranching, and mining as well as the ebbs and flows of the tourist trade. Williams has been host to the Grand Canyon Railway. This tourist railroad is one example of a tourism enterprise situated in a rural host community. Over the previous decade, the town has seen the growth of its popularity and the Railway's expansion of its depot into a full resort destination.

\subsection{Background to the Study}

Since Zimbabwe attained independence in 1980, its tourism has been associated with particular attractions and places such as the Victoria Falls, the Eastern Highlands, Kariba, National Parks, Great Zimababwe, Harare, Bulawayo, Mutare and others. Most of the recorded tourism statistics were of international visitors and they showed an upward trend as most visitors were interested in experiencing the new Zimbabwe. As noted by [5], in 1986 Zimbabwe's tourism arrivals totalled 318 666, in 1987 they were 339 328, in 1988 (412 212), 1989 (435 875), 1990 (582 602), 1991 (607 029), 1992 (675 187) and 1993 (879 501). According to [5], the average length of stay plummeted from 9 nights between 1980 and 1985 to 2 nights between 2000 and 2005. They say this is partly attributable to the fact that the global trend for long haul travel is that tourists now visit more than one country. This is the time to develop the previously marginalised small towns for tourism, but initially for domestic tourism.

\section{Research Methodology}

A phenomenological inquiry was used because the study was largely qualitative in nature. It was a descriptive research meant to unravel the perceptions of the domestic tourist. It is important to understand these perspectives in order for the stakeholders, including tourism planners, to collaborate in developing sustainable domestic tourism in the small towns. Sixty two respondents were randomly selected from the two small towns of Chinhoyi and Karoi. The survey was conducted between August 2012 and September 2013. A semi structured self - completion questionnaire was used to collect data. Data was collected both during the week and during weekends. The two- pronged approach was therefore meant to ensure that the perceptions of both the leisure and business markets were captured. The respondents were approached at hotels, restaurants and tourist attractions. A 16 - item semi - structured questionnaire was developed to capture the main themes explored in the study. These included the profile of respondents, the frequency of usage of tourism and hospitality facilities in the small towns and how the towns could be developed for domestic tourism. Data was analysed using descriptive statistics.

\section{Results And Discussion}

Sixty two questionnaires were distributed and fifty- five were returned giving a response rate of $89 \%$ which was quite high and plausible.

\section{Research question A.1: Please indicate your sex below:}

Table 1: Showing Gender Composition of Respondents

\begin{tabular}{||l||l||l||}
\hline \hline Gender & Frequency & \% \\
\hline \hline Male & 19 & $\mathbf{3 5}$ \\
\hline Female & 36 & $\mathbf{6 5}$ \\
\hline Total & $\mathbf{5 5}$ & $\mathbf{1 0 0}$ \\
\hline
\end{tabular}


Table 1 shows that the majority, $65 \%$ of the respondents were females and $35 \%$ were males. Most of the respondents $(44 \%)$ were in the $36-45$ years age bracket while $27 \%$ were aged between $26-35$ years. This fairly young to middle aged market usually has no children or have small families and fairly high disposable incomes. They are energetic too. Tourism planners could tap into this market by designing and setting up facilities in the small towns so they could stay much longer in these towns. In this regard, these towns can slowly begin to compete with anchor attractions like Kariba for the tourist's money.

\subsection{Research question B.13: What is your average household monthly income?}

Most of the respondents (55\%) were in the US\$1001 - US $\$ 1500$ income bracket. This is just about Zimbabwe's middle income zone and well above the country's poverty datum line of about US\$600. Most of the respondents $(44 \%)$ were degree holders (held first degrees) and (22\%) held postgraduate (masters) degrees. They were professionals who could contribute significantly to the economic and social well - being of the small towns as both leisure and business tourists.

\subsection{Research question B.11: What types of attractions would you like to visit in this town?}

Most of the respondents $(51 \%)$ indicated that they preferred historical sites like museums and monuments and thirty per cent opted for nature - based attractions like farms. Therefore, three forms of tourism namely - dark, heritage and agro- tourism are powerful draw cards in these small towns. The towns which are 88 $\mathrm{km}$ apart exist in natural regions 2 and 3 which are some of the prime farming areas in the country. The liberation war which ushered in the country's independence in 1980 started in this province. All this could be harnessed for domestic tourism development.

\subsection{Research question B. 16: Facilities to enhance domestic tourism in small towns.}

The respondents $(\mathrm{n}=55)$ were asked to indicate the facilities they thought could be introduced in Chinhoyi and Karoi to encourage the local people to participate in tourism. The majority (43\%) preferred facilities for events and a variety of entertainment including cultural entertainment. Thirty per cent required better amenities including family- friendly facilities such as lunar parks and water slides. This finding is consistent with the fact that female respondents were the majority. Quite often women prefer to share their fun and joy with family. Quality casino, movie houses, musical festivals and swimming pools at hotels in both small towns were considered appropriate facilities that could assist to grow the towns for domestic tourism. The Chinhoyi golf course could be exploited for various golf events.

\section{Conclusion}

Most of the respondents undertake domestic tourism from time to time. They visit anchor attractions like Victoria Falls, the Eastern Highlands, Kariba and Great Zimbabwe. They know exactly the tourism and hospitality facilities which enhance their holiday experiences. This adds weight to the validity and reliability of the research findings. Further, the majority were highly educated professionals. For a long time in Zimbabwe small towns have played second fiddle to anchor attractions. They have come to be known as conduits and transit zones linking tourists to the major tourist resorts and yet with the growth of the concept of route tourism, they can grow gradually in a continuum, to become destinations. Small towns are an integral component of the tourism system. It is widely acknowledged that an over dependence on international tourism and on anchor attractions can be very risky hence the need to explore opportunities for domestic tourism development. Domestic tourism is now generally respected as a "shock absorber" to cushion against "external shocks". The previously marginalized small towns provide an opportunity for domestic tourism development.A similar study could be conducted incorporating service providers' perceptions. Also, the concept of route tourism is a subject requiring scholarly inquiry in Zimbabwean tourism. Route tourism entails linking together a series of tourism attractions in order to promote local tourism development by encouraging visitors to travel from one location to another.

\section{References}

[1] S. J. Page and J. Connell, Tourism - A modern synthesis $2^{\text {nd }}$ edition, (Thomson Learning, London, 2006)

[2] UNWTO - Report on initial findings on the study on domestic tourism across Asia and the Pacific, Twenty-fourth Joint Meeting, Chiang Mai, Thailand, 4 May 2012

[3] M. J. Lamont, Independent bicycle tourism: a whole tourism systems perspective, tourism analysis, 2009, Vol. 14, N0, 5 pp, 605 620

[4] J.S. Davis and D.B. Morais, Factions and enclaves: small towns and socially unsustainable tourism development, Journal of Travel Research, Vol. 43, August 2004, 3-10

[5] Zimbabwe Tourism Authority (ZTA): Tourism trends and statistics annual report, 2005 